\title{
Combined GABA-immunocytochemistry and TMB-HRP histochemistry of pretectal nuclei projecting to the inferior olive in rats, cats and monkeys
}

\author{
A K E Horn* and K -P Hoffmann \\ Abtellung fur Vergleichende Neurobiologie, Universitat Ulm, Ulm (F R G)
}

(Accepted 21 October 1986)

Key words Nucleus of the optıc tract, Infenor olıve, $\gamma$-Amınobutync acıd, Horseradısh peroxıdase.

Tetramethylbenzidine, Monkey, Cat, Rat

\begin{abstract}
Cells in the pretectal nucleus of the optic tract (NOT) of rats cats and monkeys were retrogradely labeled with horseradish peroxIdase (HRP) stereotaxically injected into the inferior olive (IO) A procedure for stabilizing the tetramethylbenzıdıne (TMB)-HRP reaction product was used to visualize combined TMB-HRP and immunohistochemically localized $\gamma$-aminobutyric acid (GABA) in the same sections Positive GABAergic reaction product was found to be restricted to smaller-size intrinsic neurons Larger NOT cells projecting to the $\mathrm{IO}$ were consistently free of GABA reaction product and, in addition, appeared to be contacted by relatively few GABAergic terminals
\end{abstract}

A specific population of neurons in the nucleus of the optic tract (NOT) and the dorsal terminal nucleus of the accessory optic tract (DTN) in the pretectum of mammals is involved in the control of horizontal optokınetic nystagmus4 6101213162330 These neurons receive a visual projection mainly from the contralateral eye $\mathrm{e}^{126}$ as well as from the ipsilateral visual cortex $^{27} 34$ and they in turn project to the ipsilateral dorsal cap of the inferior olive $(\mathrm{IO})^{142833}$ The outstanding property of these NOT and DTN neurons is their directionally specific response to temporal to nasal movement of full-field visual stımulı presented to the contralateral eye $e^{46101213}$ The results of pharmacological experıments suggest that $\gamma$-amınobutyric acid (GABA) plays an important role in the initiation of direction specificity in cells of the retina and visual cortex ${ }^{29}$ 36 Inhibitory GABAergic cells may also shape the preterred direction of directional cells in the NOT or mediate their inhibition caused by movement in the non-preferred direction Recent immunocytochemical studies have shown the presence of neurons within the NOT and DTN in a num- ber of mammals that use GABA as a neurotransmit$\operatorname{ter}^{4} 19212235$ In the present study we investigated the possible structural basıs for a direction selectıve mechanism in the NOT and DTN by determining whether neurons projectıng to the $\mathrm{IO}$ are contacted by GABAergic terminals We used the retrograde axonal transport of horseradish peroxıdase (HRP) to label NOT and DTN neurons, and combined HRP histochemistry with subsequent immunocytochemical methods for the localization of GABA

Four pigmented rats, two normally pigmented cats and two monkeys (Macaca mulatta) were used For the stereotaxic injection of HRP each animal was deeply anesthetized Rats were given a single dose of Nembutal $(5 \mathrm{mg} / 100 \mathrm{~g})$ and cats as well as monkeys were given an initial subcutaneous injection of ketamine $(20 \mathrm{mg} / \mathrm{kg}$ ) in combination with Rompun (0 05 $\mathrm{ml} / \mathrm{kg}$ ), followed by subsequent doses of ketamıne $(10 \mathrm{mg} / \mathrm{kg})$ i $\mathrm{v}$ given as needed durıng surgery The cats and monkeys were intubated and artificially venthlated with a mixture of $\mathrm{N}_{2} \mathrm{O} / \mathrm{O}_{2}\left(\begin{array}{ll}3 & 1\end{array}\right)$ to maintain adequate anesthesı

\footnotetext{
* Present address Physiologisches Institut, Pettenhoterstr 128000 Muenchen 2 F R G

Correspondence K-P Hoffmann Abt f Vergleichende Neurobılogie Unıversitat Ulm Oberer Eselsberg D-7900 Ulm F R G
} 
Each anımal was subsequently placed in an appropriate stereotaxic instrument To approach the IO in rats and cats, the foramen magnum was enlarged and the durd excised to expose the medulla oblongata The caudal part of the cerebellum was gently elevated to visualize the forth ventricle and a Hamilton microliter syrınge was advanced towards the IO For rats, the microliter syringe was inserted to a depth of $27 \mathrm{~mm}$ through the midline of the opening of the obex angled forward at an angle of $5^{\circ}$ A similar approach was used tor the first cat The syringe was inserted $1 \mathrm{~mm}$ lateral to the obex, angled $45^{\circ}$ forward and advanced $7 \mathrm{~mm}$ below the brainstem surface $A$ second cat received an HRP injection into the lateral geniculate nucleus The syringe was stereotaxically guided with reference to the atlas of Berman ${ }^{3}$, and its final positıon was determıned by electrophysıological recording of visually evoked activity In the monkey, the IO was approached stereotaxically according to the atlas of Snyder and Lee ${ }^{31}$ with a syringe angled forward $45^{\circ}$ The rats received $01 \mu \mathrm{l}$, the cats and monkeys received $02 \mu \mathrm{l}$ of a $30 \%$ HRP solution in $2 \%$ dimethylsulfoxıde (DMSO) in distılled water All injections were made slowly over a period of $20 \mathrm{~min}$

Following a survival period of $72 \mathrm{~h}$ after an injection into the IO, and $45 \mathrm{~h}$ after the injection into the geniculate body, the anımals were deeply anesthetized and perfused transcardially with the following solutions (1) 1 liter Ringer $(09 \% \mathrm{NaCl})$ with $01 \%$ Novocain at $37{ }^{\circ} \mathrm{C}$, (2) 3 liters of a fixatıve consisting of $1 \%$ paraformaldehyde and $1 \%$ glutaraldehyde in $01 \mathrm{M}$ phosphate buffer ( $\mathrm{pH} 74$ ) at $4{ }^{\circ} \mathrm{C}$ and (3) 1 hter of a second fixative consisting of $2 \%$ paraformaldehyde and $01 \%$ glutaraldehyde at $4{ }^{\circ} \mathrm{C}$ The brains were immediately blocked and stored overnight in $01 \mathrm{M}$ phosphate buffer The next day, 20-40 $\mu \mathrm{m}$ se- rial sections of the midbrain were cut on a vibratome and collected in $01 \mathrm{M}$ phosphate buffer All sections were tirst processed for HRP-dctivity with tetramethylbenzidıne (TMB) as a chromogen In order to demonstrate transported HRP and GABA-immunohistochemistry in the same section the following modification of the Mesulam ${ }^{1 \times}$ protecol for TMB-hıstochemistry was used

\section{HRP protocol}

(1) Rinse sections 6 times in ice-cold distilled water

(2) Preincubate in a mixture of solution A $100 \mathrm{mg}$ sodium nitroferricyanide, $925 \mathrm{ml}$ distilled water and $5 \mathrm{ml} 02 \mathrm{M}$ citrate buffer ( $\mathrm{pH} 33$ ), and B $5 \mathrm{mg} \mathrm{TMB}$ dissolved in $25 \mathrm{ml}$ of reagent grade absolute alcohol

(3) Incubate by adding $200 \mathrm{mg} \beta$-D-glucose, $40 \mathrm{mg}$ ammonium chloride and $05 \mathrm{mg}$ glucose oxıdase (GOD) (instead of $\left.\mathrm{H}_{2} \mathrm{O}_{2}\right)^{15}$, to $100 \mathrm{ml}$ of preincubation bath for about 40 min untıl the desired degree of staining is obtained

(4) Stabilize TMB in an ice-cooled 5\% ammonium heptamolybdate (AHM) solution ${ }^{8,20}$ for $20 \mathrm{~min}$ (note without this initial stabilization, TMB reaction product may be lost in the second stabilization step.)

(5) Rinse sections $30 \mathrm{~s}$ in $01 \mathrm{M}$ phosphate buffer (pH 7 4)

(6) Further stabilize TMB for $5-8$ min with DAB$\mathrm{Co}$ as described by Rye et al ${ }^{25}$ prepare a solution of $50 \mathrm{mg}$ DAB in $100 \mathrm{ml} 01 \mathrm{M}$ phosphate buffer ( $\mathrm{pH}$ 74 ), and while stırring slowly add $25 \mathrm{ml}$ of a $1 \%$ cobalt acetate solution dropwise, followed by addition of $\mathrm{H}_{2} \mathrm{O}_{2}$ (for a final dilution of $001 \% \mathrm{H}_{2} \mathrm{O}_{2}$ )

(7) Rinse 5 times in cold $001 \mathrm{M}$ phosphate-buffered salıne (PBS), $\mathrm{pH} 73$

Fig 1 Micrographs showing the black tetramethylbenzidine (TMB) reaction product of retrogradely transported horseradish perox Idase (HRP) and the brown label of $\gamma$-aminobutyric acid (GABA) from an immunoreaction with GABA-antubody (Immuno Nuclear) in the same section Solid black arrowheads point to GABAergic terminals (puncta) on somata and proximal dendrites of retrogradely labeled cells Open black arrows point to cells not retrogradely labeled but outlined by dense clusternng of GABAergic terminals White arrows point to GABAergic neurons A GABAergic neuron in the pengeniculate nucleus of a cat The brown soma and dendrite are clearly visible due to their high content of GABA In addition, the soma contains the granular black TMB reaction product due to the retrogradely transported HRP from an injection into the lateral geniculate nucleus B cell in the intermediate layers of the superior colliculus in the cat The cell was retrogradely labeled by an HRP injection into the inferior olive and GABAergic puncta (marked by black arrows) outhne soma and dendrites These terminals probably stem from the nigrotectal projection ${ }^{17} \mathrm{C}-\mathrm{F}$ cells in the nucleus of the optic tract retrogradely labeled by HRP injections into the inferior olive are not GABAergic C monkey ( $M a c a c a$ mulatta) D pigmented rat E,F cat In contrast to the collicular neuron (B) the pretectal neurons are contacted by only a few GABAergic terminals Bars $=25 \mu \mathrm{m}$ 

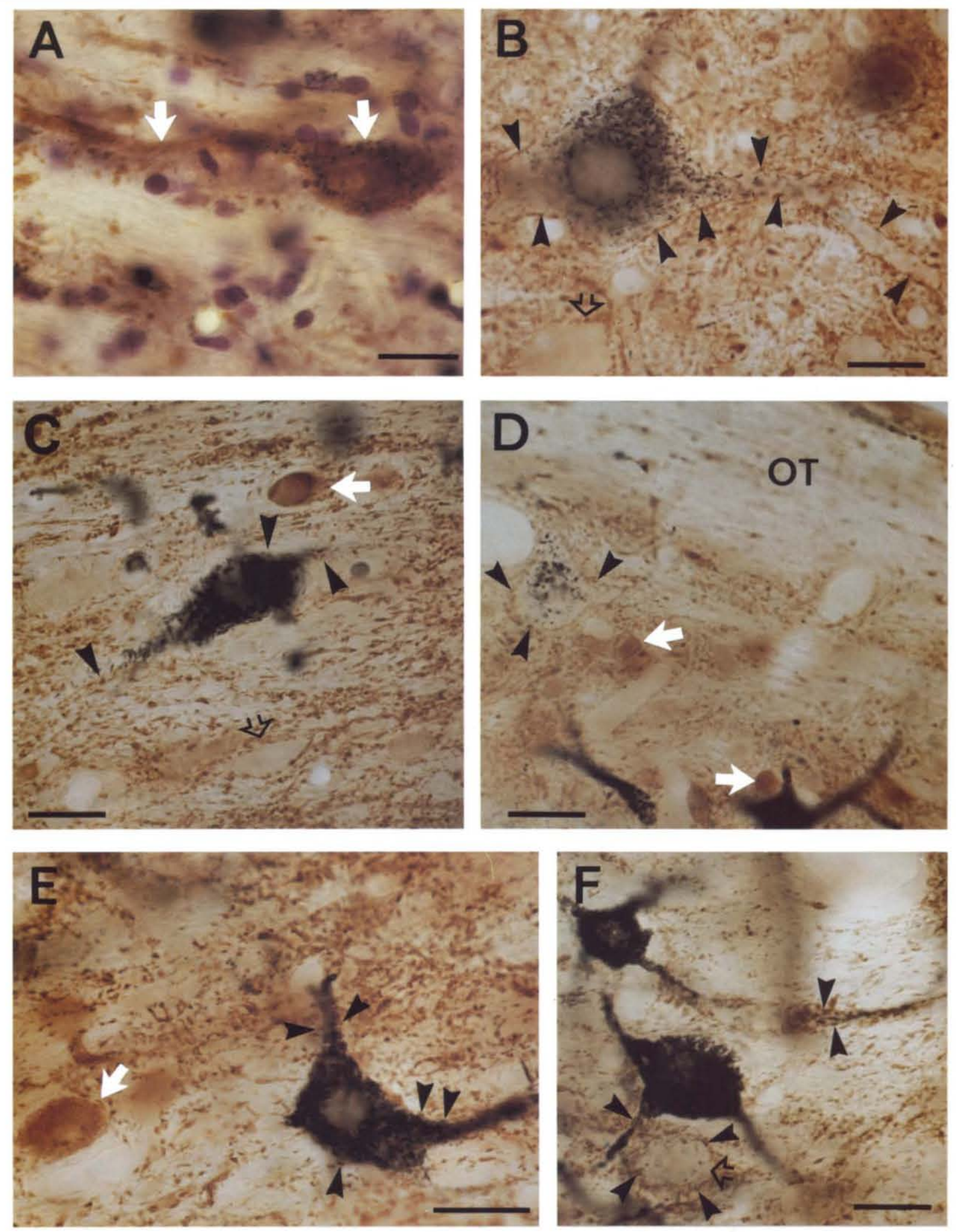
After completion of the HRP reaction, the freefloating sections were processed for GABA-immunocytochemistry using the unlabeled antibody peroxidase-antiperoxidase (PAP) method ${ }^{32}$. Sections were first incubated in $10 \%$ methanol $/ 3 \% \mathrm{H}_{2} \mathrm{O}_{2}$ to destroy the remaining activity of HRP and endogenous peroxidases. Non-specific background staining was suppressed incubating the sections for $30 \mathrm{~min}$ at room temperature in $10 \%$ normal swine serum (NSS) with $0.5 \%$ Triton X-100 in PBS. Then the sections were incubated for $12-16 \mathrm{~h}$ in a solution at $4{ }^{\circ} \mathrm{C}$ containing rabbit anti-GABA serum (Immuno Nuclear Corp) diluted 1:3000 in PBS containing 5\% NSS and $0.5 \%$ Triton X-100. The specific antigen was labeled by subsequently incubating the sections in swine antirabbit IgG (Dakopatts) diluted 1:100 in the same solution for $1 \mathrm{~h}$ at room temperature (RT), and in rabbit PAP (Dakopatts) diluted 1:50 in PBS for $1 \mathrm{~h}$ at RT. The PAP complexes were visualized by a $5-10$ min incubation in the freshly prepared solution consisting of $0.05 \% \mathrm{DAB}$ in $0.05 \mathrm{M}$ Tris-buffered saline (TBS), $\mathrm{pH} 7.6$ and $0.01 \% \mathrm{H}_{2} \mathrm{O}_{2}$ or by $20-30 \mathrm{~min}$ incubation using the DAB-glucose oxidase method of Itoh et al. ${ }^{15}$ without cobalt. As a control, some sec. tions were incubated in a solution in which the primary antibody was replaced with normal rabbit serum. After rinsing, mounting and drying, alternate sections were counterstained with $0.1 \%$ Cresyl violet before dehydrating and coverslipping.

The double-label method resulted in homogeneous brown labeled GABA-positive cell structures and granular black-labeled retrogradely transported HRP contained in neurons. The two labels were clearly distinguishable from one another by color and appearance of the reaction product (Fig. 1). GABAimmunoreactivity was found primarily in cell bodies and punctate profiles determined from electron microscopic studies to be axon terminals ${ }^{24}$. Due to limited ability of the antibody to penetrate the tissue GABA-positive labeling is restricted to the outer 8 $\mu \mathrm{m}$ of the section's surface. As a control, we first verified two critical points: (1) both markers can be independently demonstrated in the same cell, and (2) GABAergic terminals can be distinguished on retrogradely labeled cells. For the first point we performed the control experiment described by Fitzpatrick et al. ${ }^{7}$. The neurons of the perigeniculate nucleus are known to be GABAergic and they project

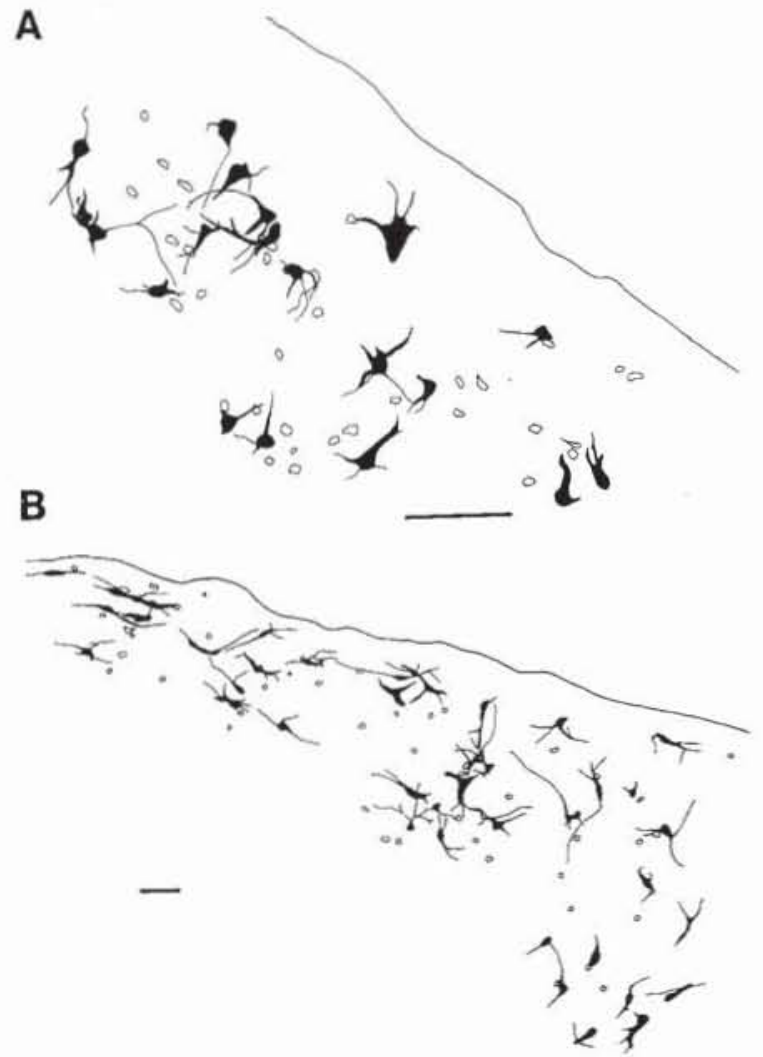

Fig. 2. Camera lucida drawings showing close proximity and size difference between cells in the nucleus of the optic tract projecting to the inferior olive (black) and GABAergic somata (open outlines). A: rat. B: cat. Bars $=100 \mu \mathrm{m}$.

to the lateral geniculate body. Following injections of HRP into the lateral geniculate body of a cat, we were able to demonstrate GABA-immunoreactivity in retrogradely labeled cells of the perigeniculate nucleus (Fig. 1A). To prove the second point, we examined the large cells in the intermediate layers of the superior colliculus which were retrogradely filled with HRP after IO injections. These neurons receive a substantial input from the substantia nigra pars reticulata $^{5,11}$. Lu et al. ${ }^{17}$ have demonstrated that these terminations are glutamate decarboxylase (GAD) immunoreactive. Fig. 1B shows a retrogradely labeled neuron in the intermediate layer of the cat's superior colliculus outlined by numerous GABA-immunoreactive terminals. These technical controls verify the validity of our observations concerning cells in the pretectum. In our material, in rat, cat and monkey the distribution of GABA-immunoreactive neuronal somata and terminals in the vicinity of retrogradely labeled pretectal cells resembles that 
observed in previous studies using antibodies to $\mathrm{GABA}^{21}$ or to the synthesızıng enzyme glutamate decarboxylase $(G A D)^{91935}$ (Fig 1D-F) In no case did we find any NOT or DTN neuron labeled for both the presence of transported HRP and GABA-ımmunoreactivity Measurements of cell body areas in the NOT revealed that in rat as well as cat, GABA-positive neurons are significantly smaller than retrogradely labeled cells in the same section ( $U$-test, $P<$ $001)$ The line drawings shown in Fig 2 illustrate the relatıve size and positions of the GABAergic intrinsic and non-GABAergic projection neurons in the NOT of rat and cat Simılar relations were found in the monkey By countıng every GABA-ımmunoreactive and Nissl-stained neuron in samples taken trom the NOT, we estimated the relative proportion of GABA-positive neurons in this nucleus In both rat and cat, GABA-positive neurons made up about $30^{c} c$ of the total neuronal population in the NOT We have also examıned the relative proportion of GABA-immunoreactive neurons in the superficial layer (SGS) of the superior colliculus, a structure that also receives and processes visual information from the retına and visual cortex The proportion of GABA-positive neurons in the SGS of the cat $\left(47^{\circ} \mathrm{C}\right)$ is signiticantly higher than in the corresponding area of the rat $\left(30^{c / c}\right)$

Using the double-label method, it was possible to demonstrate in some cases retrogradely labeled neurons with their somata and/or proximal dendrites closely associated with GABA-positive puncta resembling presumed nerve terminals ( $F_{1}$ 1 $1 \mathrm{C}-\mathrm{F}$ ) These projection neurons, however, were contacted by only a few GABA-positive terminals, suggestıng that GABAergic interactions are weak or restricted to the distal part of the dendrites Since the appear-

1 Ballas I Hoftmann K-P and Wagner, H J Retınal proJection to the nucleus of the optic tract in the cat as revealed by retrograde transport of horseradish peroxidase Neurosct Lett 26(1981) 197-202

2 Ballas I and Hottmann K-P A correlation betueen receptive field properties and morphological structures in the pretectum of the cat $J$ Comp Neurol 238 (1985) $417-428$

3 Berman 4 L The Bramstem of the Cat, The universtv of Wisconsin press 1968

4 Cazın L Prccht. W and Lannou J Pathways mediatıng optohinetic responses of vestibular neurons in the rat Pflugers fich $38+(1980) 19-29$ ance of stained GABA-positive terminals is restricted to the surface of the section and therefore the examination, too, no attempt has been made to systematically quantıfy the number of GABA-positıve termınals associated with NOT neurons projectıng to the IO

These results were critically dependent upon the tormulation of the new two-step procedure for stabilizing the TMB-HRP reaction product Since the TMB-reaction product is normally unstable in neutral butfers, subsequent immunocytochemical stainIng usually causes a marked loss of reaction product This difficulty was overcome using the stabilization protocol of Rye et al ${ }^{25}$, combining the sensitivity of TMB with the stability of the DAB-redction product Furthermore, we tound that the preceding incubation step with $5 c_{i c} \mathrm{AHM}^{\mathrm{k} 20}$ prevented the loss of TMB-reaction product previously observed durnng the short DAB reaction

Our results specifically disprove the hypothesis ${ }^{14}$ that the NOT-DTN cells send a GABAergic projection to the IO Similar double labeling studies with HRP injections into the MTN or contralateral NOT should be performed to point out whether the reciprocal connections between the NOT and other pretectal and accessory optic nucleı are GABAergic Such inhibitory interactions are assumed to contribute to the distinct direction selectivits of neuronal populations in these nuclet

This work was supported by Grants DFG Ho $450 / 17$ and Forschungsschwerpunkt 24 of the state of Baden-Wuerttemberg We thank the members of the Department of Clinical Morphology for their hind technical help, Dr R Erıckson for critıcally readıng the manuscript and C Distler for typing it

5 Chevalier $G$ Thierry A M Shibazahı $T$ and Feger J Evidence for a GABAergic inhibitory nigrotectal pathway in the rat Veurowe Lett 21 (1981) 67-7i)

6 Collewijn $H$ Direction-selective units in the rabbit s nucleus of the optic tract Bram Research 100) (1975) $489-508$

7 Fitzpatrich D Pennev G R and Schmechel DE Glutamic acid decarboxvlase-immunoreactive neurons and terminals in the lateral geniculate nucleus of the cat $J$ Neuro$\mathrm{sCl}, \mathrm{f}(1984) 1809-1829$

8 Fuju $M$ and Kusama T. Fixation of horveradish peroxIdase reaction products with ammonium molvbdate Neuros( Res 1(1984) 153-156 
9 Gioll, R A , Peterson, G M . Ribak, C E, McDonald, $H$ M , Blanks, R H I and Fallon, J H , GABAergic neurons comprise a major cell type in rodent visual relay nucleı an immunocytochemical study of pretectal and accessory optic nucle1, Exp Brain Res, 61 (1985) 194-203

10 Grasse, K L and Cynader. M S . Electrophysıology of lateral and dorsal terminal nuclei of the cat accessory optic system J Neurophysiol , 51 (1984) 276-293

11 Graybiel, A M , Organization of the nigrotectal connection an experimental tracer study in the cat, Brain Re. search, 143 (1978) 339-348

12 Hoffmann, K-P and Distler, C, The role of direction-selective cells in the nucleus of the optic tract of cat and monkey during optokınetıc nystagmus In E L Keller and D S Zee (Eds), Advances in the Biosciences, Adaptive Processes in Visual and Oculomotor Systems, Vol 57 Pergamon, Oxford. 1986, pp 261-266

13 Hoffmann, K-P and Schoppmann, A, A quantitative analysis of the direction-specific response of neurons in the cat's nucleus of the optic tract, Exp Brain Res, 42 (1981) $146-157$

14 Hoffmann, K -P , Behrend, K and Schoppmann, A , A direct afferent visual pathway from the nucleus of the optic tract to the inferior olive in the cat, Brain Research 115 (1976) $150-153$

15 Itoh, K . Konıshı, A , Nomura, S , Mizuno, N , Nakamura, $\mathrm{Y}$ and Sugimoto, $\mathrm{T}$ Application of coupled oxidation reaction to electron microscopic demonstration of horseradısh peroxıdase cobalt-glucose oxıdase method Brain Research, 175 (1979) 341-346

16 Kato, I, Harada, K. Hasegawd, T, Garashı I, Kolke $\mathrm{Y}$ and Kawasakı $\mathrm{T}$, Role of the nucleus of the optic tract in monkeys in relatıon to optokınetıc nystagmus, Brain Re search, 364 (1986) 12-22

17 Lu S M , Lin, C -S , Behan, M. Cant. N B and Hall W C . Glutamate decarboxylase immunoreactivity in the intermediate grey layer of the superior colliculus in the cat Neuroscience, 16 (1985) 123-131

18 Mesulam, M-M. Tetramethylbenzıdine tor horseradish peroxidase neurohistochemistry a non-carcinogenic blue reaction product with superior sensitivity for visualization of neuron afferents and efferents $J$ Histochem Cvto. chem , 26 (1978) 106-117

19 Mugnain, E and Oertel, W H , An atlas of the distribution of GABAergic neurons and terminals in the rat CNS as revealed by $\mathrm{GAD}$ immunohistochemistry In $\mathrm{A}$ Bjorklund and T Hokfelt (Eds), Handbook of Chemical Neuroanatomy, GABA and Neuropeptides in the CNS, Vol 4. Part 1 . 1985

20 Olucha, F, Martunez-Garcia F and Lopez-Garcia, C A new stabilizing agent for the tetramethylbenzıdine (TMB) reaction product in the histochemical detection of horseradish peroxidase (HRP), J Neurosu Meth, 13 (1985)
$131-138$

21 Otterson, O P and Storm-Mathısen, J, GABA-contaınıng neurons in the thalamus and pretectum of the rodent, Anat Embryol, 170 (1984) 197-207

22 Penney, G R Conley, M, Schmechel, DE and Didmond, I T The distribution of glutamic acid decarboxylase immunoreactivity in the diencephalon of the opossum and rabbit. J Comp Neurol, 228 (1984) 38-56

23 Precht $\mathrm{W}$ and Strata, P, On the pathway-mediatıng optokınetic responses in vestibular nuclear neurons. Neurosctence, 5 (1980) $777-787$

24 Rubak, C E , Vaughn, J E and Roberts, E, The GABA neurons and their axon terminals in rat corpus striatum as demonstrated by GAD immunohistochemistry $J$ Comp Neurol, 187 (1979) 261-284

25 Rye. D B . Saper C B and Wainer B H , Stabilizing of the tetramethylbenzıdine (TMB) reaction product application for retrograde and anterograde tracing and combination with immunohistochemistry. J Histochem Cytochem. 32 (1984) $1145-1153$

26 Scalıa, F and Arango, V. Topographic organization of the projections of the retına to the pretectal region in the rat $J$ Comp Neurol, 186 (1979) 271-292

27 Schoppmann, A . Projections trom areds 17 and 18 of the visual cortex to the nucleus of the optic tract, Brain Research, 223 (1981) 1-17

28 Sekıyd, $\mathrm{H}$ and Kawamura, $\mathrm{K}$, An HRP study in the monkey of olivary projections from the mesodiencephalic structures with particular reference to pretecto-olivary neurons Arch Ital Btol, 123(1985) 171-183

29 Sillito. A M , Inhibitory processes underlying the directional specificity of simple complex and hypercomplex cells in the cat's visual cortex. J Physiol , 271 (1977) 699-720

30 Simpson, J I The accessory optic svstem Ann Rev Neu roscl 7 (1984) 13-41

31 Snider R S and Lee, J C A Stereotaxtc Atlas of the Mon he) Brain (Macaca mulatta), The University of Chicago press

32 Sternberger, L A. Immunocvtochemistrv 2nd edn W1ley, New York 1979 p 354

33 Terasawa, K. Otanı $K$ and Yamada J, Descending pathways of the nucleus of the optic tract in the rat, Brain Research, 173 (1979) 405-417

34 Updyke B V. Topographic organization of the projectons from cortical areas 17,18 and 19 onto the thalamus pretectum and superior colliculus in the cat, J Comp Neurol, $173(1977) 81-121$

35 Weber, J T and Chen, I-L, GAD immunoreactivity in the pretectal complex of the cat, Soc Neurosct Abstr, 10 (1984) 576

36 Wyatt $\mathrm{HJ}$ and Daw N W Spectic effects of neurotransmittcr antdgonists on ganghon cells in rabbit retind Science 191 (1976) 204-205 